Jurnal Ekonomi, Bisnis, dan Akuntansi (JEBA) Volume 21 Nomor 03 Tahun 2019

\title{
PENGARUH PENGALAMAN MEREK TERHADAP KESETIAAN MEREK DIMEDIASIKAN OLEH KECINTAAN MEREK, KEPERCAYAAN MEREK, DAN KETERKAITAN MEREK
}

\author{
Wisanggeni Bagus Anggoro ${ }^{1 *}$, Suliyanto ${ }^{2}$, Rahab $^{3}$ \\ Manajemen, Universitas Jendral Soedirman, Indonesia \\ *Email Penulis: wisanggeni.b.a@gmail.com
}

\begin{abstract}
Abstrak
Penelitian ini bertujuan untuk meneliti pengaruh pengalaman merek terhadap kesetiaan merek yang di mediasikan oleh kecintaan terhadap merek, kepercayaan merek, dan keterkaitan merek.Dalam penelitian ini survey dilakukan terhadap 150 pengguna telepon pintar Samsung di purwokerto. Hipotesis yang diajukan dalam penelitian ini diuji menggunakan alat analisis structural equation modeing (SEM). Hasil menunjukan adanya pengaruh positif antara pengalaman merek yang dimediasikan oleh kecintaan merek dan kepercayaan merek, namun tidak pada keterkaitan merek sebagai variabel moderasi antara pengalaman merek dan kesetiiaan merek.
\end{abstract}

Kata Kunci: Pengalaman merek, kesetiaan merek, kecintaan merek, kepercayaan merek, keterkaitan merek.

\begin{abstract}
This research intend to investigate the effect of brand experience on brand loyalty mediated by brand love, brand trust, and brand attachment. In this research survey has been done to 150 samsung smartphone user in Purwokerto. Hyphotesis testing done by using structured equation modeling (SEM). The result of this research shows that brand experience has positif effect on brand loyalty moderated by brand love and brand trust, yet brand attachment has no mediating effect on the effect of brand experience to the brand loyalty
\end{abstract}

Keyword: Brand Experience, loyalty, love, trust, attachment, samsung.

\section{PENDAHULUAN}

Persaingan dalam bisnis sekarang semakin ketat. Akhir-akhir ini banyak produsen memproduksi barang yang hampir sama. Hal ini dapat dilihat dengan melihat jumlah pangsa pasar telepon pintar yang saling bersaing dalam meraih angka penjualan terbesar. Namun hingga awal tahun 2017 telepon pintar Samsung masih memimpin pangsa pasar telepon pintar di Indonesia dengan memegang angka 21,9\% dari pangsa pasar telepon pintar di Indonesia. Disusul oleh apple dengan pangsa pasar sebesar 15,2 \% disusul oleh Huwawei pada urutan ketiga dengan pangsa pasar sebesar 10,8\%, Oppo pada urutan ke empat dengan pangsa pasar sebesar 7,6 \%, dan vivo pada urutan kelima dengan pangsa pasar sebesar 6,6 \%, Xiaomi ada pada urutan keenam dengan nilai pangsa pasar sebesar 6,4\% dan merek telepon pintar lain sebesar $31,6 \%$ 
Dengan melihat persaingan yang begitu ketat tersebut membuat perusahaan harus berfikir bagaimana membuat agar konsumen tetap setia pada merek mereka. Salah satu strategi yang digunakan adalah strategi merek. Jika seorang konsumen telah menjadi konsumen yang setia, maka mereka akan menjadi nilai lebih bagi sebuah perusahaan. Banyak faktor yang mempengaruhi kesetiaan merek antara lain pengalaman merek, kecintaan merek, kepercayaan merek, dan keterkaitan merek. (Huang., 2017; Chitoui., 2016).

Penelitian sebelumnya oleh Huang (2017) telah meneliti mengenai mekanisme hubungan antara pengalaman merek dengan kesetiaan merek, dengan menambahkan dua variabel sebagai variabel mediasi yakni kecintaan terhadap merek dan kepercayaan terhadap merek, kedua variabel tersebut dapat disebut sebagai tahapan identifikasi terhadap merek. Identifikasi merek mengacu pada 'keadaan psikologis konsumen' dalam memahami, merasakan, dan menilai keanggunan sebuah merek (Lam., Ahearne dan Schillewaert., 2011). (Yang, et al, 2017) menemukan bahwa pengalaman merek berpengaruh positif terhadap kesetiaan merek, ia berpendapat bahwa komunikasi online dapat mempengaruhi pengalaman merek yang selanjutnya akan mengarah kepada kesetiaan merek. Karena merek dapat mentransfer makna simbolis kepada konsumen, maka hal itu dapat membantu konsumen mengidentifikasi diri dan idealisme mereka sendiri (Lam, et al., 2011).

Pada penelitian sebelumnya identifikasi merek dibedakan menjadi dua yaitu kecintaan terhadap merek (brand love) dan kepercayaan merek (brand trust) (Huang, 2017).namun pada penelitian tersebut masih terdapat kekurangan yaitu identifikasi merek hanya menjelaskan hubungan dua variabel mediasi yang mengakibatkan posisi identifikasi merek masih belum cukup kuat sebagai variabel mediasi sehingga penelitian tersebut masih memerlukan pengembangan. Pada penelitian tersebut (Huang, 2017) menyarankan untuk menambahkan variabel mediasi salah satunya keterkaitan merek (brand attachment) pada model resonansi merek.

\section{Telaah Pustaka}

\section{Kesetiaan Merek}

Kesetiaan merek dapat didefinisikan sebagai tingkat kesetiaan konsumen terhadap merek tertentu.Kesetiaan ini diungkapkan melalui pembelian berulang dan perilaku positif lainnya seperti promosi dari mulut ke mulut, terlepas dari tekanan pemasaran yang dihasilkan oleh merek pesaing lainnya (Kotler, et al., 2008). Menurut Mowen dan Minor (2009) kesetiaan merek adalah suatu kondisi dimana konsumen mempunyai sikap positif terhadap sebuah merek, mempunyai komitmen pada merek tersebut, dan bermaksud meneruskan pembeliannya di masa mendatang. Definisi ini didasarkan pada dua pendekatan yaitu behavioral dan attitudinal. Kesetiaan merek merupakan tingkat kesetiaan konsumen terhaadap merek tertentu dan dapat dilihat melalui pembelian berulang, dan perilaku positif lain seperti promosi dari mulut ke mulut, memilki komitmen terhadap merek, dan berniat melakukan pembelian dimasa datang, yang berdasar pada sikap dan perilaku konsumen. 
Oliver (1997) menyebutkan bahwa pelanggan setia melewati empat tahap.Tahap pertama adalah rasa kognitif (belief).Misalnya, promosi penjualan atau produk berkualitas tinggi dari perusahaan untuk pertimbangan pembelian pertama kali menarik pelanggan.Untuk menjadi loyal, pelanggan harus secara konsisten memastikan bahwa harapannya terhadap barang atau jasa terpenuhi.Tahap kedua adalah rasa afektif (sikap positif) di mana konsumen berulang kali puas dengan keputusan pembelian.Tahap ketiga adalah tahap dimana konsumen memiliki niat perilaku - berkomitmen untuk membeli secara mendalam.Tujuannya mengarah pada tahap keempat tindakan.Pelanggan memiliki keinginan untuk mengatasi hambatan, misalnya, daya tarik pesaing atau kenaikan harga oleh perusahaan untuk mencapai perilaku pembelian yang sebenarnya. Fullerton dalam Nugroho (2011:17), membagi tingkat kesetiaan konsumen dalam tiga tahap, antara lain: (a). Kesetiaan advokasi, merupakan sikap pelanggan untuk memberikan rekomendasi kepada orang lain untuk melakukan pembelian ulang terhadap produk atau jasa. Kesetiaan advokasi pada umumnya disertai dengan pembelaan konsumen terhadap produk atau jasa yang dipakai. (b). Kesetiaan repurchase, kesetiaan pelanggan berkembang pada perilaku pembelian pelanggan terhadap layanan baru yang dikeluarkan oleh suatu perusahaan, yang ditunjukkan dengan keinginan untuk membeli kembali. (c). Kesetiaan paymore, kesetiaan pelanggan untuk kembali melakukan transaksi untuk menggunakan produk atau jasa yang telah dipakai oleh konsumen tersebut dengan pengorbanan yang lebih besar. Kesetiaan merek pada umumnya bertujuan pada pembelian ulang sebuah merek oleh konsumen. Dalam mewujudkan tujuan trsebut melalui berbagai macam tahapan antara lain kognitif ,afektif, perilaku, dan terahir adalah tindakan, namun pendapat lain ada yang menyatakan kesetiaan terdiri dari tiga tahapan saja yaitu kesetiaan advokasi, kesetiaan repurchase dan kesetiaan paymore. Loyalalitas tersebut dilihat darimaksudnya memiliki artian yang sama yaitu pembelian ulang oleh konsumen.

Menurut Huang (2017) ada beberapa indikator yang menunjukkan bahwa seseorang dinyatakan setia pada sebuah merek antara lain saat konsumen melakukan pembelian terus menerus dan memiliki keinginan membeli produk dimasa yang akan datang, komitmen konsumen secara psikologi dan yakin bahawa merek tersebut unik, Keadaan psikologis konsumen dalam melihat, merasakan, dan menghargai sebuah merek. Sedangkan menurut Kabadayi dan Alan (2012) ada tiga indikator yang meenandakan seseorang sudah menjadi konsumen yang loyal. Ciri ciri tersebut antara lain adalah seseorang dinyatakan loyal jika ia akan kembali membeli merek yang sama dimanapun ia berada, konsumen mulai merekomendasikan merek yang ia senangi kepada orang lain (WOM) seseorang akan membeli lagi merek yang dia senangi dimasa yang akan dating berdasrkan penelitian sebelumnya maka dapat disimpulkan bahwa ciri ciri seseorang yang sudah setia kepada merek adalah saat konsumen akan tetap menggunakan sebuah merek yang selama ini mereka gunakan. Selain itu juga jika seorang konsumen sudah mulai menyarankan sebuah merek kepada orang terdekat maka mereka dapat dikatakan sudah menjadi konsumen yang loyal. Saat seorang konsumen memiliki keyakinan bahwa merek tersebut merupakan merek yang unik, dan sesuai dengan keinginan psikologisnya secara otomatis dia akan menggunakan merek yang sama dimasa yang akan dating hal ini juga merupakan indikasi bahwa seorang konsumen sudah dinyatakan loyal. 


\section{Kecintaan Merek}

Kecintaan terhadap merek adalah sebuah konsep dari psikologi sosial.Berdasarkan pola hubungan dan anggapan bahwa konsumen dapat mengaitkan karakteristik manusia dengan merek, komunitas ilmiah mulai menekankan pada ketidakmampuan konsep cinta dan keterikatan.(Albert dan Florence, 2008).Carroll dan Ahuvia (2006) mendefinisikan cinta terhadap merek sebagai 'tingkat keterikatan emosional yang bergairah yang dimiliki konsumen yang puas terhadap sebuah merek dagang tertentu.Kecintaan terhadap merek merupakan ikatan emosional antara konsumen dengan merek dagang tertentu yang dapat timbul dikarenakan adanya kepuasan dari pengalaman sebelumnya saat menggunakan merek dagang tersebut.

Menurut Keh et al., (2007) cinta terhadap merek merupakan komitmen jangka panjang. Bagi seorang konsumen untuk mencintai sebuah merek diperlukan komitment pada sebuah merek termasuk emosi dan gairah. Ahuvia (2005) melaporkan bahwa seseorang membutuhkan hubungan mendalam antara konsumen dengan sebuah produk yang dilihatnya sebagai identitas yang diinginkan agar konsumen menyukai produk tersebut. Untuk mencapai sesuatu yang disebut dengan kecintaan merek seorang konsumen harus memiliki ikatan emosional yang mendalam dengan sebuah produk dimana konsumen akan mencari identitas yang dia inginkan dari sebuah produk.

Pada penelitian sebelumnya Bergvist (2010) menggunakan 2 pertanyaan indikator yang menunjukkan kecintaan seseorang terhadap sebuah merek yang pertama adalah apakah seseorang akan merindukan sebuah merek jika menghilang dari pasaran, dan yang kedua adalah apakah seseorang memiliki hubungan emosional seperti rasa mencintai terhadap sebuah merek. Dari kedua pertanyaan tersebut maka dapat disimpulkan bahwa indicator dari kecintaan merek adalah komitmen menggunakan merek tersebut secara berkelanjutan, dan juga adanya keterikayan konsumen dengan sebuah merek secara emosional.Sedangkan penelitian selanjutnya oleh Huang (2017) menyatakan ada lebih banyak indikator kecintaan terhadap merek antara lain adalah rasa cinta terhadap merek, perasaan yang ditimbulkan saat menggunkan merek tertentu, ketertarikan terhadap merek, dan keterikatan emosional terhadap merek.Indikator dari kecintaan merek memiliki hubungan dengan ikatan emosional antara konsumen dengan sebuah merek.disamping itu juga adanya perasaan yang timbul juka seseorang menggunakan merek tertentu. Hal ini dikarenakan konsep dasar dari kecintaan merek itu sendiri yang merupakan konsep dari psikologi social yang digabungkan dengan konsep dari pemasaran.

\section{Kepercayaan Merek}

Kepercayaan merek didefinisikan sebagai perasaan aman yang dimiliki oleh konsumen dalam interaksinya dengan merek yang berdasar pada persepsi bahwa merek tersebut dapat diandalkan dan bertanggung jawab untuk kepentingan dan kesejahteraan konsumen (balester dalam Huang, 2017).Kepercayaan merek didefinisikan sebagai sejauh mana seseorang percaya diri dan melakukan tindakan yang diinginkan berdasarkan kata-kata, tindakan, dan keputusan 
orang lain (McAllister dalam kiyani et al., 2012) Kepercayaan merek dapat didefininisikan sebagai sejauh mana konsumen merasa aman dalam interaksinya dalam menggunkanan sebuah merek yang mereka yakini bahwa merek tersebut dapat diandalkan dan dapat bertanggungjawab.

Menurut Gurviez dan Korchia (2003) ada beberapa hal-hal dapat diidentifikasi dari kepercayaan.Pertama, kepercayaan dan komitmen adalah variabel terpenting dalam menjaga hubungan jangka panjang di antara para mitra dalam bisnis dan industri.Kedua, penjelasan dari kepercayaan dan komitmen dalam hubungan antara perusahaan dan konsumen memberikan suplemen untuk teori bisnis terutama tentang biaya transaksi.Ketiga, yang terbesar kesulitan membangun kepercayaan konsep berada dalam kognitif dan berbasis afektif. Menurut ballester dan alleman (2003) Pengembangan kepercayaan merek merupakan proses jangka panjang. Pelanggan dapat percaya pada merek jika merek tersebut dapat memenuhi harapan pelanggan, memenuhi janji dan menghargai pelanggannya yang akhirnya mengarah pada kepercayaan dan keandalan sebuah merek.Seorang konsumen memerlukan waktu yang cukup lama untuk mempercayai sebuah merek.konsumen tersebut perlu menggunakan atau mencoba sebuah merek sehingga mereka dapat percaya bahwa merek tersebut terpercaya.

Sahin et al., (2011) menyatakan bahwa kepercayaan merek memiliki dua dimensi. Dimensi pertama yaitu keandalan, yaitu keadaan saat sebuah merek memiliki sifat secara teknis kompeten dalam memenuhi janji dan memenuhi kebutuhan konsumen.Dimensi kedua dinilai dari niat baik sebuah merek yang berkaitan dengan kepentingan dan kesejahteraan konsumen, misalnya ketika masalah tak terduga pada produk muncul (pemberian garansi).Huang (2017) melihat kepercayaan merek terdiri dari dua dimensi.Dimensi pertama adalah fiabilitas, hal ini menyangkut persepsi bahwa merek dapat memenuhi atau memuaskan kebutuhan konsumen.Hal ini terkait dengan keyakinan individu bahwa merek tersebut memenuhi janji nilainya. Dimensi kedua adalah Intentionalitas, hal ini berkaitan dengan keamanan emosional pada individu, dan menggambarkan aspek keyakinan pada bukti yang tersedia untuk membuat individu merasa aman dengan jaminan bahwa merek akan bertanggung jawab dan peduli meskipun terjadi perubahan situasi atau adanya masalah pada produk di masayang akan datang. Kepercayaan merek dapat dicapai jika meek memberikan bukti bahwa mereka bertanggung jawab terhadap produknya dimasa yang akan dating dan berjanji akan memuaskan keinginan konsumen.

\section{Keterkaitan Merek}

Keterikatan merek merupakan suatu konsep yang merujuk pada rasa aman yang dirasakan konsumen terhadap sebuah merek (Japutra et al., 2014).Literatur pemasaran menggambarkan keterikatan merek sebagai predisposisi emosional konsumen dalam jangka panjang terhadap suatu merek (Ghose dan Lowengart, 2013).Ketika pelanggan berinteraksi dengan lingkungan pasar, mereka mengembangkan ikatan yang mengikat mereka dengan merek produk (Keller, 2008).Menurut Park et al., (2010), keterikatan merek dapat didefinisikan sebagai "kekuatan ikatan yang menghubungkan merek dengan diri" dan sifat-sifat konseptualnya dapat ditampilkan menurut dua faktor penting; koneksi merek-diri dan keunggulan merek. Keterkaitan merek merupakan suatu konsep yang mengacu pada rasa aman 
yang dirasakan konsumen terhadap suatu produk, rasa aman ini nantinya akan menciptakan suatu ikatan yang kuat yang menghubungkan merek dengan diri konsumen.

Bahri-Ammari (2015) menemukan ada 2 faktor yang mempengaruhi keterkaitan merek secara positif dan signifikan, dua variaber tersebut adalah kepuasan dan hubungan kenangan (nostalgic connection) hal ini dikarenakan semakin seseorang merasa puas terhadap sebuah merek kemungkinan mereka akan merasa terkait pada merek tersebut, begitu juga dengan nilai nostalgia, seseorang yang merasa terpuaskan pada sebuah merek jika merek tersebut kembali beredar mereka akan menggunakan lagi dikarenakan mereka merasa terkait dengan merek tersebut. Kang et al., (2016) menemukan bahwa keterkaitan merek dipengaruhi oleh pengalaman merek, hal ini dikarenakan keterkaitan merek merupakan variabel yang memiliki unsur perasaan dan emosi yang akan dipengaruhi oleh pengalaman merek yang juga memiliki unsur afketif dan kognitif. Selain itu jika seseorang merasa memiliki pengalaman yang menyenangkan terhadap sebuah merek kemungkinan mereka akan terkait. Keterkaitan merek merupakan variabel dengan dimensi emosi dan perasaan yang mendalam hal ini tentu dapat dipengaruhi oleh variabel lain yang memiliki unsur afektif kognitif dan juga emosi seperti kepuasan terhadap merek, dan pengalaman merek.

Fournier (1994) telah mengusulkan keterkaitan merek sebagai salah satu dari enam dimensi yang relevan dalam hubungan merek konsumen.Pentingnya keterikatan merek sebagai penentu utama dalam perilaku konsumsi konsumen dibuktikan oleh beberapa atribut yang melekat pada konsep tersebut.Keterikatan mengekspresikan ikatan emosional yang gigih, menolak untuk berubah, memengaruhi kognisi, dan memprediksi perilaku (Krosnick dan Petty, 1995).Ketekunan mencerminkan sejauh mana keterikatan individu terhadap suatu objek tetap tidak berubah dari waktu ke waktu.Perlawanan mewakili kemampuan individu untuk menolak beralih ke produk kompetitif (Petty dan Cacioppo, 1986). Keterikatan yang kuat akan menyebabkan resistensi konsumen terhadap perubahan dan kemampuan merek untuk menahan kinerja buruk (Keller et al., 2008). Park et al., (2006) mengandaikan bahwa keterikatan merek lebih dari sekadar konstruk sikap dan menyumbang perilaku konsumen tingkat tinggi yang dikaitkan dengan komitmen terhadap suatu hubungan. Dengan demikian, keterikatan merek adalah karakteristik hubungan antara konsumen dan merek yang mengarah ke "pengambilan otomatis pikiran dan perasaan tentang merek" (Park et al., 2006).Keterikatan merek melibatkan komponen afektif dari suatu merek, mewakili berbagai kondisi emosional seperti menyukai, perasaan hangat, atau gairah (Belaid \& Behi, 2011).Pelanggan cenderung mempersonifikasikan merek yang disukai dan dengan demikian membangun afiliasi dekat dengannya (Halloran, 2014).Dalam psikologi, teori keterkaitan menunjukkan bahwa semakin kuat keterikatan seseorang terhadap suatu entitas, semakin mungkin untuk mempertahankan hubungan dengan entitas (Bowlby, 1980; Thomson et al., 2005).Pelanggan merasakan kesenangan dan mengalami stabilitas emosional melalui pengembangan keterikatan emosional yang kuat dengan merek tertentu (Belaid \& Behi, 2011; Yu, Kim, \& Auh, 2013).Keterikatan yang kuat dapat didasarkan pada interaksi berkelanjutan antara pelanggan dan merek (Thomson et al., 2005). Keterkaitan merek memiliki berbagai komponen indikator yang berkaitan dengan 
Jurnal Ekonomi, Bisnis, dan Akuntansi (JEBA) Volume 21 Nomor 03 Tahun 2019

komponen komponen perasaan dan emosi yang akan membuat konsumen terkait pada sebuah merek dan meningkatkan rasa penolakan untuk berubah

\section{Pengalaman Merek}

Brakus, et al., (2009) menyatakan bahwa pengalaman merek adalah 'respons konsumen internal subjektif (sensasi, perasaan, dan kognisi, dan respons perilaku), yang ditimbulkan oleh rangsangan terkait merek yang merupakan bagian dari desain dan identitas merek, seperti kemasan, komunikasi, dan lingkungan. Menurut Alloza (2008), pengalaman merek dapat didefinisikan sebagai persepsi konsumen, pada setiap saat konsumen melakukan kontak langsung terhadap merek, baik itu pada citra merek yang dibentuk melalui iklan, saat pertama kali menggunakan merek, atau tingkat kualitas yang dirasakan konsumen saat menggunakan merek. Pengalaman merek tercipta saat pelanggan menggunakan merek, berbicara dengan orang lain tentang merek, dan mengikuti informasi merek, iklan, acara, dan lain-lain (Ambler et al., 2002). Pengalaman merek merupakan persepsi konsumen saat konsumen melakukan kontak langsung dengan merek terkait dengan faktor internal konsumen seperti sensasi, perasaan, dan respon saat melihat atau menggunakan merek.

Pine dan Gilmore (1999) mempelajari "pengalaman yang bertingkat" di lingkungan ritel dan event.Pada keadaan ini, konsumen membedakan sebuah merek berdasarkan unsur estetika seperti (termasuk aspek visual, pendengaran, penciuman, dan perasa), tingkat pendidikan, perlakuan, dan pengalihan.Namun demikian tingkatan pengalaman merek ini hanya terbatas pada situasi ritel saja. Schmitt (1999) mengusulkan lima tingkatan pengalaman merek antara lain melalui; sensasi, merasakan, berpikir, bertindak, dan berhubungan. Seseorang akan mendapatkan pengalaman dari sebuah merek jika mereka telah merasakan sensasi sebuah merek, berfikir tentang sebuah merek, bertindak atau berusaha dalam mendapatkan sebuah merek, dan juga berhubungan langsung dengan merek.Pengalaman merek memiliki beberapa macam tingkatan yang semuanya berhubungan sengan emosi, sifat kognitif, afektif dan perilaku. Semua hal tersebut dapat diperoleh jika seorang konsumen telah berinteraksi secara langsung dengan sebuah merek baik itu hanya dari melihat iklan saja atau menggunakan sebuah produk.

Brakus et al., (2009) mengemukakan ada empat jenis pengalaman merek: sensorik, afektif, intelektual dan perilaku. Pengalaman sensoris menggambarkan estetika dan atribut sensorik yang dapat dideteksi oleh pelanggan melalui organ sensorik mereka (Hwang dan Hyun, 2012).Aspek visual merek bisa meningkatkan pengalaman sensoris karena merangsang indera pelanggan termasuk bau, penglihatan, Sentuhan, dan pendengaran (Brakus et al., 2009).Pengalaman afektif terdiri dari semua jenis pengalaman subjektif yang terkait dengan perasaan dan emosi tertentu (Hwang dan Hyun, 2012). Pelanggan menciptakan persepsi merek, baik positif (Cinta, keinginan, dan harga diri) atau negatif (Takut, dan putus asa) (Miao, Lehto, dan Wei Wei, 2014). Pengalaman perilaku mengacu pada jenis respons perilaku tertentu terhadap merek yang dipicu oleh Rangsangan merek tertentu (Shim, Forsythe, dan Kwon, 2015).Individu didorong untuk berpartisipasi Dalam tindakan fisik atau pengalaman fisik yang mencoba menciptakan pengalaman dan interaksi yang nyata Dengan konsumen lain (Wang, 2014).Pengalaman intelektual didefinisikan sebagai peristiwa yang merangsang pemikiran 
individu atau membuat mereka merasa penasaran (Lee dan Kang, 2012).Istilah "intelektual" mengacu pada merangsang kreativitas melalui kejutan, intrik dan provokasi dan menghasilkan kenangan jangka panjang tentang sebuah merek di benak pelanggan (Schmitt, 1999).

\section{Perumusan Hipotesis}

(Ha dan Perks, 2005) menyatakan bahwa pengalaman merek dapat bersifat positif atau negatif, bersifat sementara atau jangka panjang. Selain itu, pengalaman merek dapat berdampak positif terhadap kepuasan konsumen, kesetiaan merek, dan kepercayaan merek. Sahin et al., (2011) menyatakan bahwa pengalaman merek memiliki pengaruh positif terhadap kepercayaan merek, dan kesetiaan merek. Hand dan Li (2012) Menyatakan bahwa terdapat hubungan yang kuat antara pengalaman merek dan kesetiaan merek, secara langsung terkait dengan kesetiaan sikap, dan secara tidak langsung terkait dengan kesetiaan perilaku. Huang (2017) menemukan bahwa pengalaman merek memiliki pengaruh positif terhadap kesetiaan merek dengan kecintaan merek dan kepercayaan merek sebagai variabel mediasi.

Berdasarkan pendapat tersebut jika seorang konsumen mengalami pengalaman yang baik saat menggunakan sebuah merek, kemungkinan besar mereka akan menggunakan merek di masa yang akan mendatang yang akan menghasilkan pembelian berulang. Hal tersebut mengindikasikan bahwa pengalaman merek berpengaruh terhadap kesetiaan merek.Berdasarkan argumen serta penelitian terdahulu dapat dirumuskan hipotesis sebagai berikut..

H1 : Pengalaman merek memiliki pengaruh positif terhadap kesetiaan merek.

Kecintaan terhadap merek merupakan sebuah konsep psikologi sosial (Shimp dan Madden, 1988). Jika seseorang memiliki pengalaman yang baik kemungkinan orang tersebut akan mencintai sebuah merek. Huang et al., ( 2017) menemukan bahwa pengalaman merek memiliki pengaruh positif terhadap kecintaan terhadap merek. Meisenzahi (2017) menyatakan bahwa pengalaman merek dapat mempengaruhi kecintaan merek, hal ini dikarenakan merupakan variable yang memiliki unsur emosional. Sedangkan Rodrigues et al., (2015) menemukan bahwa pengalaman merek dapat berpengaruh terhadap kecintaan merek, terutama pada pengalaman sensorik, afektif, dan intelektual. Batra, et al., (2012) berpendapat bahwa kecintaan merek dapat didefinisikan sebagai suatu hubungan tetapi juga sebagai emosi sehingga pengalaman merek dapat memengaruhi kecintaan merek.

Berdasarkan beberapa pendapat tersebut maka dapat disimpulkan jika seorang konsumen mendapatkan pengalaman yang baik selama menggunakan sebuah merek, mereka akan merasa bahwa merek tersebut memberikan nilai lebih terhadap mereka dan pada akhirnya konsumen akan mencintai merek tersebut. Hal tersebut mengindikasikan bahwa pengalaman merek berpengaruh terhadap kecintaan merek.Berdasarkan argumen serta penelitian terdahulu dapat dirumuskan hipotesis sebagai berikut.

H2 : Pengalaman merek memiliki pengaruh positif terhadap kecintaan merek. 
Brakus et al., (2009) menyatakan bahwa konsep pengalaman penting untuk memahami dan mengelola kepercayaan merek dan kesetiaan merek. Pengalaman merek dapat bersifat positif atau negatif, secara sementara, atau jangka panjang. Selain itu, pengalaman merek dapat berdampak positif terhadap kepuasan konsumen,kesetiaan merek, dan kepercayaan merek (Ha dan Perks, 2005). Huang (2017) menemukan bahwa pengalaman merek berpengaruh secara signifikan terhadap kepercayaan merek.

Berdasarkan beberapa pendapat tersebut maka dapat disimpulkan jika seorang konsumen mendapatkan pengalaman yang baik saat menggunakan sebuah merek, mereka akan merasa bahwa merek tersebut dapat menjaga kepercayaan konsumen bahwa produk yang mereka gunakan akan selalu menjamin produk yang digunakan merupakan produk yang terbaik. Hal tersebut mengindikasikan bahwa pengalaman merek berpengaruh terhadap kepercayaan merek Berdasarkan argumen serta penelitian terdahulu dapat dirumuskan hipotesis sebagai berikut.

H3 : Pengalaman merek memiliki pengaruh positif terhadap kepercayaan merek.

Keterikatan merek mengacu pada "kekuatan ikatan secara kognitif dan afektif yang menghubungkan merek dengan diri sendiri" (Park et al., 2006).Pengalaman merek menggambarkan sebuahpersepsi pelanggan saat mereka melihatsebuah merek (Alloza, 2008).Selama konsumen berinteraksi dengan sebuah merek, mereka akan membentuk ikatan emosional dengan pengalaman yang mereka rasakan hal ini yang disebut dengan keterkaitan merek (Yu et al., 2013). Mikulincer dan Shaver (2005) berpendapat bahwa konsumen dapat mempertahankan stabilitas emosional dan semakin optimis saat sebuah merek tetap memberikan pengalaman yang memuaskan. Selain itu, Dolbec dan Chebat (2013)., Lee, Jeon, dan Yoon (2010), membahas dampak dari pengalaman merek terhadap keterkaitan merek.

Berdasarkan beberapa pendapat penelitian sebelumnya maka dapat dijelaskan bahwa kemungkinan jika seseorang memiliki pengalaman yang baik dalam menggunakan sebuah produk maka mereka akan membentuk ikatan emosional yang akan membuat mereka merasa terkait terhadap produk tersebut. Hal tersebut mengindikasikan bahwa pengalaman merek berpengaruh terhadap kepercayaan merek.Berdasarkan argumen serta penelitian terdahulu dapat dirumuskan hipotesis sebagai berikut.

H4 : Pengalaman merek memiliki pengaruh positif terhadap keterkaitan merek.

Kecintaan merek terdiri dari banyak jenis emosi, seperti gairah, sikap positif dan evaluasi, menyukai, keterikatan, komitmen dan lain-lain (Batra et al., 2012). Jika konsumen menyukai merek, mereka mungkin merasa memiliki kesetiaan merek yang lebih besar, keinginan untuk menggunakan, kemauan untuk menginvestasikan lebih banyak sumber daya untuk membelibeli sebuah merek, kesetiaan perilaku, lebih terlibat dalam menentukan sebuah merek, menyebarkan secara positif dari mulut ke mulut (WOM), dan kesetiaan sikap (Carroll dan Ahuvia, 2006). Albert et al., (2009) menyatakan bahwa kecintaan merek memprediksi loyalitas merek, kepercayaan merek dan Word of mouth. Skoog dan Soderstrom (2015) menyatakan ada beberapa variabel yang dapat dipengaruhi antara lain adalah komitment 
merek dan kesetiaan merek. Huang (2017) menemukan bahwa kecintaan merek memiliki pengaruh positif terhadap kesetiaan merek.

Berdasarkan poenelitian sebelumnya dapat disimpulkan bahwa semakin seseorang mencintai sebuah merek maka orang tersebut cinderung akan lebih setia terhadap merek dan enggan berpindah pada merek lain. Hal ini mengindikasikan bahwa kecintaan terhadap sebuah merek akan memicu terjadinya kesetiaan merek. Berdasarkan argumen serta penelitian terdahulu dapat dirumuskan hipotesis sebagai berikut.

H5 : Kecintaan merek memiliki pengaruh positif terhadap kesetiaan merek.

Kepercayaan merek merupakan elemen penting dalam pemasaran karena kita bisa menghasilkan Kesetiaan merek yang tinggi. Pelanggan Kesetiaan tinggi memiliki kemungkinan untuk menarik lebih banyak pelanggan yang laten, oleh karena itu kebanyakan operator biasanya akan mempromosikan Kesetiaan merek ke daftar sebagai target operasi utama Upamannyu et al. (2013). Corbitt et al., (2003) telah menunjukkan bahwa efek positif yang kuat dari kepercayaan pada loyalitas pelanggan dalam kasus sektor telekomunikasi. Huang (2013) menyatakan bahwa kepercayaan merek memiliki pengaruh positif terhadap kesetiaan merek dan merupakan variabel yang memediasai hubungan antara pengalaman merek dengan kesetiaan merek.

Berasarkan hasil penelitian sebelumnya dapat disimpulkan bahwa semakin orang memiliki kepercayaan terhadap merek maka akan semakin setia terhadap merek tersebut hal ini dikarenakan konsumen cinderung enggan mengambil resiko untuk menggunakan merek lain. Hal ini mengindikasikan bahwa semakin percaya seseorang terhadap sebuah merek maka mereka akan semakin setia pada sebuah merek. Berdasarkan argumen serta penelitian terdahulu dapat dirumuskan hipotesis sebagai berikut.

H6 : Kepercayaan merek memiliki pengaruh positif terhadap kesetiaan merek.

Park et al. (2006) berpendapat bahwa keterikatan merek lebih dari sekedar konstruksi sikap dan menyumbang perilaku konsumen yang terkait dengan komitmen terhadap suatu hubungan.Dengan demikian, keterikatan merek adalah karakteristik hubungan antara konsumen dan merek yang mengarah pada "pengambilan kembali pikiran dan perasaan secara otomatis tentang merek (Park et al., 2006).Reaksi afektif terhadap merek telah digunakan untuk memprediksi kesetiaan merek.Studi empiris melaporkan bahwa pengaruh merek menentukan kesetiaan pembelian dan sikap (Chaudhuri dan Holbrook, 2001) sedangkan keterikatan merek secara langsung mempengaruhi Kesetiaan merek (Thomson et al., 2005).Chitoui (2016) menyatakan bahwa keterikatan dapat merek menjelaskan kesetiaan perilaku konsumen secara jelas.

Berdasarkan hasil penelitian sebelumnya maka dapat disimpulkan bahwa jika seseorang sudah menganggap merek itu sebagai symbol mengenai dirinya maka mereka akan semakin setia terhadap merek tersebut. Hal ini dikarenakan jika mereka berpindah kepada 
merek lain akan merubah citra mereka. Dengan demikian dimungkinkan bahwa keterkaitan merek akan menimbulkan kesetiaan terhadap merek. Berdasarkan argumen serta penelitian terdahulu dapat dirumuskan hipotesis sebagai berikut.

H7 : Keterkaitan merek memiliki pengaruh positif terhadap kesetiaan merek.

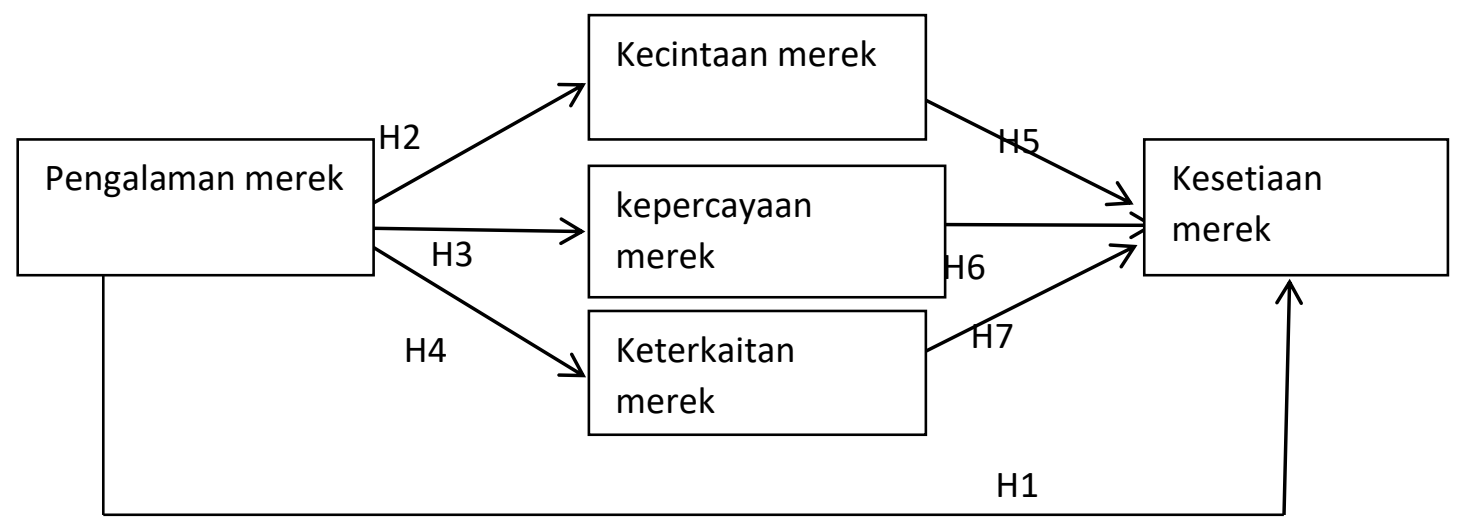

Gambar 1.1Model penelitian (2018)

\section{METODE PENELITIAN}

Jenis penelitian ini adalah penelitian kuantitatif dengan metode survey dengan menggunakan kuisioner sebagai alat untuk mengumpulkan data.Sampel dalam penelitian ini adalah pengguna telepon pintar Samsung.Variabel yang dicantumkan dalam kuisioner adalah pengalaman merek, kecintaan merek, kepercayaan merek, keterkaitan merek, dan kesetiaan merek.Teknik yang digunakan dalam pengambilan sampel adalah Accidental sampling.Kuisioner dibagikan secara langsung kepada 175 pengguna telepon pintar Samsung, namun hanya 150 kuisioner yang memenuhi kriteria penelitian.Instrument dalam penelitian ini disusun berdasarkan penelitian yang telah dilakukan oleh peneliti sebelumnya yang bersumber pada sebagian besar jurnal internasional.Instrumen penelitian menggunakan skala likert 5 poin. Analisis dilakukan dengan menggunakan metode structured equation modeling (SEM).

\section{HASIL}

Responden dalam penelitian ini terbatas hanya pada pelanggan telepon pintar merek Samsung dengan usia minimal 19 tahun yang pernah menggunakan telepon pintar Samsung minimal 1 tahun. Pengumpulan data dilaksanakan pada bulan September 2018 dengan memberikan kuisioner kepada responden yang menggunakan telepon pintar Samsung.

Setelah data terkumpul maka dilakukan 4 uji validitas antara lain Convergen validity, Variance extract, Construct reability, Discriminant validity

Tabel 4.7 Hasil Pengujian Convergent Validity

\begin{tabular}{lccccc}
\hline Construct & Items & $\begin{array}{c}\text { Cronbach } \\
\text { alpha }\end{array}$ & & & \\
\cline { 3 - 5 } & & $\begin{array}{c}\text { Loading } \\
\text { factor }\end{array}$ & $\begin{array}{c}\text { Construct } \\
\text { validity }\end{array}$ & $\begin{array}{c}\text { Variance } \\
\text { extract }\end{array}$ \\
\hline
\end{tabular}


Pengaruh Pengalaman Merek Terhadap Kesetiaan Merek Dimediasikan Oleh Kecintaan Merek, Kepercayaan Merek, dan Keterkaitan Merek

\begin{tabular}{|c|c|c|c|c|c|}
\hline \multirow[t]{2}{*}{ Construct } & \multirow[t]{2}{*}{ Items } & \multirow{2}{*}{$\begin{array}{l}\text { Cronbach } \\
\text { alpha }\end{array}$} & \multirow[b]{2}{*}{$\begin{array}{l}\text { Loading } \\
\text { factor }\end{array}$} & \multirow[b]{2}{*}{$\begin{array}{c}\text { Construct } \\
\text { validity }\end{array}$} & \multirow[b]{2}{*}{$\begin{array}{c}\text { Variance } \\
\text { extract }\end{array}$} \\
\hline & & & & & \\
\hline \multirow[t]{8}{*}{$\begin{array}{c}\text { Pengalaman } \\
\text { merek }\end{array}$} & $\mathrm{X} 1$ & 0.899 & 0.767 & 0.938 & 0.889 \\
\hline & $\mathrm{X} 2$ & & 0.718 & & \\
\hline & X3 & & 0.715 & & \\
\hline & $\mathrm{X} 4$ & & 0.778 & & \\
\hline & $\mathrm{X} 5$ & & 0.73 & & \\
\hline & X6 & & 0.711 & & \\
\hline & $X 7$ & & 0.684 & & \\
\hline & X8 & & 0.688 & & \\
\hline \multirow[t]{4}{*}{$\begin{array}{l}\text { Kecintaan } \\
\text { merek }\end{array}$} & X9 & 0.706 & 0.67 & 0.892 & 0.822 \\
\hline & $\mathrm{X} 10$ & & 0.745 & & \\
\hline & X11 & & 0.569 & & \\
\hline & $\mathrm{X} 12$ & & 0.665 & & \\
\hline \multirow[t]{5}{*}{$\begin{array}{c}\text { Kepercayaan } \\
\text { merek }\end{array}$} & X13 & 0.846 & 0.666 & 0.889 & 0.796 \\
\hline & $\mathrm{X} 14$ & & 0.681 & & \\
\hline & X15 & & 0.7 & & \\
\hline & X16 & & 0.716 & & \\
\hline & $\mathrm{X} 17$ & & 0.722 & & \\
\hline \multirow[t]{4}{*}{$\begin{array}{c}\text { Keterkaitan } \\
\text { merek }\end{array}$} & X18 & 0.862 & 0.8 & 0.839 & 0.699 \\
\hline & X19 & & 0.603 & & \\
\hline & $\mathrm{X} 20$ & & 0.699 & & \\
\hline & $\mathrm{X} 21$ & & 0.845 & & \\
\hline \multirow{4}{*}{$\begin{array}{l}\text { Kesetiaan } \\
\text { merek }\end{array}$} & $\mathrm{X} 22$ & 0.844 & 0.585 & 0.898 & 0.896 \\
\hline & $\mathrm{X} 23$ & & 0.804 & & \\
\hline & $\mathrm{X} 24$ & & 0.802 & & \\
\hline & $\mathrm{X} 25$ & & 0.795 & & \\
\hline
\end{tabular}

Berdasarkan hasil analisis tersebut, secara umum loading factor sudah signifikan secara statistik dan nilai loading factor sudah lebih dari 0,5, sehingga dapat disimpulkan bahwa masing masing indikator variabel telah valid secara konvergen.

\section{Variance Extracted}

Variance extracted dihitung dengan cara menjumlahkan kuadrat standardized factor loading (squared multiple correlation) dibagi dengan jumlah kuadrat standardizes loading ditambah jumlah varians dari error. Nilai AVE menunjukkan adanya convergent yang baik jika nilainya sama dengan atau di atas 0,50. 
Tabel 4.8 Hasil Pengujian Variance Extract

\begin{tabular}{lll}
\hline \multicolumn{1}{c}{ Variabel } & Variance Extracted \\
\hline Pengalaman Merek & 0.889 & \\
Kecintaan Merek & 0.822 & \\
Kepercayaan Merek & 0.796 & \\
Keterkaitan Merek & 0.699 & \\
Loyalitas Merek & 0.896 &
\end{tabular}

Sumber: Data diolah

Berdasarkan hasil uji variance extract, dapat disimpulkan jika nilai AVE tiap variabel memiliki nilai lebih dari 0,5 maka data ini layak untuk digunakan.

\section{Construct Reliability}

Construct Reliability dianggap menunjukan reabilitas konstruk baik jika memiliki nilai 0,70 atau lebih.

Tabel 4.9 Hasil Pengujian Construct Reliability

\begin{tabular}{lll}
\hline \multicolumn{1}{c}{ Variabel } & Construct Reliability \\
\hline Pengalaman Merek & 0.938 \\
Kecanggihan Merek & 0.892 & \\
Kepuasan Merek & 0.889 & \\
Kepercayaan Merek & 0.893 & \\
Loyalitas Merek & 0.898 & \\
\hline
\end{tabular}

Sumber: Data diolah

Berdasarkan hasil perhitungan reabilitas konstruk seperti pada tabel 4.9, diperoleh nilai reabilitas konstruk lebih dari angka $(0,70)$ sehingga dapat dinyatakan bahwa semua variabel konsisten atau reliabel.

\section{Discriminant Validity}

Uji Discriminant Validity dilakukan untuk mengetahui sejauh mana suatu indikator dalam mengukur sebuah variabel yang memiliki korelasi lebih kuat dibandingkan korelasi indikator tersebut dengan variabel lain.

Tabel 4.10 Hasil Pengujian Discriminant Validity

\begin{tabular}{lcc}
\hline Variabel & AVE & $\sqrt{\text { AVE }}$ \\
\hline Pengalaman Merek & 0.525 & 0.725 \\
Kecintaan Merek & 0.552 & 0.743 \\
Kepercayaan Merek & 0.486 & 0.697 \\
Keterkaitan Merek & 0.442 & 0.665 \\
Kesetiaan Merek & 0.566 & 0.752 \\
\hline
\end{tabular}

Sumber: Data diolah

Hasil tersebut akan dibandingkan dengan nilai dari korelasi antar konstruk pada tabel. 
Pengaruh Pengalaman Merek Terhadap Kesetiaan Merek Dimediasikan Oleh Kecintaan Merek, Kepercayaan Merek, dan Keterkaitan Merek

Tabel 4.11 Korelasi antar Konstruk dan akar kuadrat AVE

\begin{tabular}{llllll}
\hline & Pm & Kcn & Kpc & Ktk & Kes \\
\hline $\begin{array}{l}\text { Pengalaman Merek } \\
\text { Kecintaan Merek }\end{array}$ & 0.725 & & & & \\
Kepercayaan Merek & & 0.743 & & & \\
Keterkaitan Merek & & & 0.697 & & \\
Kesetiaan Merek & & 0.200 & 0.370 & -0.110 & 0.752 \\
\hline Sumber: Data diolah & & & & &
\end{tabular}

Berdasarkan tabel 4.11 dapat disimpulkan bahwa konstruk Pengalaman Merek (Pm), Kecintaan Merek (Kcn), Kepercayaan Merek (Kpc) Keterkaitan Merek (Ktk), dan Kesetiaan Merek (Kes) memiliki nilai akar kuadrat AVE lebih tinggi daripada korelasi antar konstruk lainnya dan ini menunjukkan discriminant validity yang baik.

Uji hipotesis dilakukan dengan membandingkan Critical ratio dengan nilai t tabel. Jika nilai Critical Ratio lebih besar dari nilai t tabel maka hipotesis diterima dalam penelitian ini digunakan $t$ tabel sebesar 1,96

Tabel 4.23 Uji Hipotesis

\begin{tabular}{lllllll}
\hline & & & Estimate & S.E. & C.R. & P \\
\hline B Lv & $<---$ & B Ex & .560 & .097 & 5.781 & $* * *$ \\
B Tr & $<---$ & B Ex & .918 & .119 & 7.715 & $* * *$ \\
B At & $<---$ & B Ex & .808 & .121 & 6.658 & $* * *$ \\
B Lo & $<---$ & B Lv & .196 & .096 & 2.043 & .041 \\
B Lo & $<---$ & B Tr & .366 & .166 & 2.200 & .028 \\
B Lo & $<---$ & B At & -.107 & .051 & -2.078 & .038 \\
B Lo & $<---$ & B Ex & .365 & .161 & 2.270 & .023 \\
\hline
\end{tabular}

Keterangan : ${ }^{* * *}$ : nilai $\mathrm{p}<0.001^{* *}$ nilai $\mathrm{p}<0.05$

Sumber: Data diolah

Dari tabel diatas dapat dilihat hanya terdapat 1 nilai yang lebih kecil dari t tabel yaitu nilai pengaruh keterkaitan merek terhadap kesetiaan merek, dengan demikian enam hipoteseisditerima. Sedangkan hipotesis yang menyatakan keterkaitan merek berpengaruh terhadap keterkaitan merek ditolak.

\section{PEMBAHASAN}

Berdasarkan table 4.23 pengaruh pengalaman merek terhadap kesetiaan merek menunjukan nilai CR sebesar 2.270. Hal ini menunjukan bahwa pengalaman merek berpengaruh pada kesetiaan merekdengan tingkat signifikansi sebesar $<0.023$. Hal ini 
menandakan bahwa tingkat signifikansi pengaruh pengalaman merek terhadap kesetiaan merek masih dianggap signifikan pada tingkat kesalahan 0.05 .

Pengalaman merek berpengaruh positif pada Kesetiaan merek. Hal ini mengindikasikan bahwa semakain baik pengalaman yang dialami konsumen selama menggunakan telepon pintar Samsung, maka konsumen akan semakin setia kepada telepon pintar merek Samsung.

Berdasarkan table 4.23 pengaruh pengalaman merek terhadap kecintaan merek menunjukan nilai CR sebesar 5.781. Hal ini menunjukan bahwa pengalaman merek berpengaruh pada kesetiaan merekdengan tingkat signifikansi sebesar $<0.001$

Pengalaman merek berpengaruh positif pada kecintaan merek. Hal ini mengindikasikan semakin banyak pengalaman baik yang digunakan telepon pintar Samsung, maka konsumen akan semakin mencintai telepon pintar Samsung dan menyukai merek Samsung.

Berdasarkan table 4.23 pengaruh pengalaman merek terhadap kepercayaan merek menunjukan nilai CR sebesar 7.715. Hal ini menunjukan bahwa pengalaman merek berpengaruh pada kesetiaan merekdengan tingkat signifikansi sebesar $<0.001$

Pengalaman merek berpengaruh positif pada kepercayaan merek. Hal ini mengindikasikan jika seorang konsumen memiliki banyak pengalaman baik selama menggunakan telepon pintar Samsung, maka mereka secara langsung akan percaya bahwa merek Samsung merupakan merek yang dapat dipercayai kualitasnya.

Berdasarkan table 4.23 pengaruh pengalaman merek terhadap keterkaitan merek menunjukan nilai CR sebesar 6.658.Hal ini menunjukan bahwa pengalaman merek berpengaruh pada kesetiaan merekdengan tingkat signifikansi sebesar $<0.001$.

Pengalaman merek berpengaruh positif pada keterkaitan merek. Hal ini mengindikasikan semakin baik pengalaman yang dirasakan oleh konsumen selama menggunakan telepon pintar Samsung, maka mereka akan merasa terkait dengan merek telepon pintar Samsung bahkan mereka akan merasa bahwa telepon pintar Samsung merupakan pencerminan diri mereka.

Berdasarkan table 4.23 pengaruh kecintaan merek terhadap kesetiaan merek menunjukan nilai CR sebesar 2.043.Hal ini menunjukan bahwa pengalaman merek berpengaruh pada kesetiaan merekdengan tingkat signifikansi sebesar 0.041.Hal ini menandakan bahwa tingkat signifikansi pengaruh pengalaman merek terhadap kesetiaan merek masih dianggap signifikan pada tingkat kesalahan 0.05 .

Kecintaan merek berpengaruh positif pada kesetiaan merek. Hal ini mengindikasikan semakin konsumen cinta terhadap merek telepon pintar Samsung maka mereka akan semakin enggan untuk berpindah kepada telepon pintar merek lain.

Berdasarkan table 4.23 pengaruh kecintaan merek terhadap kesetiaan merek menunjukan nilai CR sebesar 2.200.Hal ini menunjukan bahwa pengalaman merek berpengaruh pada kesetiaan merekdengan tingkat signifikansi sebesar 0.028 . Hal ini menandakan bahwa 
tingkat signifikansi pengaruh pengalaman merek terhadap kesetiaan merek masih dianggap signifikan pada tingkat kesalahan 0.05 .

Kepercayaan merek berpengaruh positif pada kesetiaan merek. Hal ini menandakan bahwa semakin konsumen mempercayai kualitas dari telepon pintar Samsung, maka mereka akan semakin setia kepada merek telepon pintar Samsung hingga enggan berpindah kepada merek telepon pintar lain yang belum tentu baik serta mereka akan merekomendasikan telepon pintar Samsung kepada kerabat dan teman teman.

Selain daripada itu pengalaman yang baik saat konsumen menggunakan produk telepon pintar Samsung akan membuat konsumen percaya bahwa produk telepon pintar Samsung akan memberikan yang terbaik bagi konsumen dan menjamin kepuasan terhadap konsumen. Hal ini akan berpengaruh langsung kepada keputusan konsumen menggunakan telepon pintar Samsung dimasa yang akan datang, bahkan merekomendasikan produk telepon pintar Samsung kepada orang yang mereka kenal.

\section{KESIMPULAN DAN SARAN}

Berdasar hasil penelitian dapat disimpulkan bahwa pengalaman merek berpengaruh terhadap kesetiaan merek, kecintaan merek, kepercayaan merek, dan keterkaitan merek. Kecintaan merek juga berpengaruh terhadap kesetiaan merek. Sama halnya dengan kepercayaan merek yang juga berpengaruh terhadap kesetiaan merek. Dengan demikian dapat disimpukan bahwa kecintaan merek dan kepercayaan berperan sebagai variabel mediasi yang menghubungkan pengaruh dari pengalaman merek terhadap kesetiaan merek. Dalam penelitian ini pengalaman merek berpengaruh terhadap keterkaitan merek.Namun keterkaitan merek memiliki pengaruh negatif kepada kesetiaan merek.Dengan demikian keterkaitan merek tidak memiliki peranan sebagai variabel mediasi.

Sebagai penelitian empiris, hasil dari penelitian ini dapat digunakan oleh pihak telepon pintar Samsung sebagai pertimbangan dalam meningkatkan kesetiaan konsumen.Untuk meningkatkan kesetiaan konsumen pihak telepon pintar Samsung dapat memilih 3 jalur. Pertama pihak telepon pintar Samsung adapt meningkatkan pengalaman merek yang akan meningkatkan kecintaan merek kemudian meningkatkan kesetiaan merek. Kedua pihak telepon pintar Samsung dapat memilih jalur meningkatkan pengalaman merek kemudian kepercayaan merek lalu kesetiaan merek. Ketiga pihak telepon pintar Samsung dapat meningkatkan pengalaman merek yang langsung akan mempengaruhi kesetiaan merek.

Penelitian yang akan datang dapat dilakukan dengan menambahkan variabel lain yang mungkin mempengaruhi hubungan antara keterkaitan merek dengan kesetiaan merek seperti gender, usia, atau variabel lain yang dimungkinkan memiliki peranan sebagai variabel moderasi. Selain itu penelitian mendatang dapat dilakukan dengan menerapkan model pada produk lain. 


\section{Daftar Pustaka}

. 2011. Ekonometrika Terapan : Teori \& Aplikasi dengan SPSS. CV. Andi Offset, Yogyakarta.

Albert, N.; Merunka, D. and Valette-Florence, P. (2009), "The feeling of love toward a brand: Concept and Measurement", Advances in Consumer Research, 36, 300-307.

Bergkvist, L. and Bech-Larsen, T. (2010), "Two studies of consequences and actionable antecedents of brand love", Brand Management, 7(7), 504-518.

Bhattacharya, C. B. and Sen, S. (2003), "Consumer-company identification: a framework for understanding consumers' relationships with companies". Journal of Marketing, Vol. 67, No. 2, pp. 76-88.

Bhattacharya, C. B. and Sen, S. (2003), “Consumer-company identification: a framework for understanding consumers' relationships with companies". Journal of Marketing, Vol. 67, No. 2, pp. 76-88.

Brakus, J., Schmitt, B.and Zarantonello, L. (2009), "Brand experience: what is it? how is it measured? does it affect loyalty?", Journal of Marketing, Vol. 73, No. 3, pp. 52-68.

Carroll, B.A. and Ahuvia, A.C. (2006), "Some antecedents and outcomes of brand love", Marketing Letters, Vol. 17, No. 2, pp. 79-89.

Chao-Chin Huang, (2017) "The impacts of brand experiences on brand loyalty: mediators of brand love and trust", Management Decision, Vol. 55 Issue: 5, doi: 10.1108/MD-10-20150465

Chaudhuri, A. and Holbrook, M.B. (2001), "The chain of effects from brand trust and brand affect to brand performance: the role of brand loyalty", Journal of Marketing, Vol. 65, No. 2, pp. 81-93.

Delgado-Ballester, E. and Munuera-Alemán, J.L. (2001), "Brand trust in the context of consumer loyalty", European Journal of Marketing, Vol. 35, No. 11/12, pp. 
Delgado-Ballester, E., \& Munuera-Alemán, J. L. (2005), “Does brand trust matter to brand equity?” Journal of Product \& Brand Management, Vol. 14, No. 3, pp. 187-196.

Delgado-Ballester, E., Munuera-Aleman, J.L. and Yague-Guillen, M.J. (2003), “Development and validation of a brand trust scale",International Journal of Market Research, Vol. 45, No. 1, pp. 35-54.

Dick, A.S. and Basu, K. (1994), “Customer loyalty: toward an integrated conceptual framework”. Journal of the Academy of Marketing Science, Vol. 22, No. 2, pp. 99-113.

Ebru Tümer KABADAYI Alev KOÇAK ALAN .(2012), “BRAND TRUST AND BRAND AFFECT: THEIR STRATEGIC IMPORTANCE ON BRAND LOYALTY",Journal of Global Strategic Management | V. 6 | N. 1 | 2012-June | isma.info | 80-88 | DOI:

$10.20460 / J G S M .2012615788$

Farid Yuniar Nugroho. 2011. Pengaruh Citra Merek dan Kepuasan Pelanggan Terhadap Loyalitas Konsumen. Yogyakarta: Fakultas Pertanian Universitas Pembangunan Nasional "Veteran".

Gurviez, P., Korchia, M. (2003). Test of a consumer-brand relationship model, including trust and three consequences. Thirtieth International Research Seminar in Marketing

Ha, H.Y. and Perks, H. (2005), "Effects of consumer perceptions of brand experience on the web: brand familiarity, satisfaction and brand trust". Journal of Consumer Behaviour, Vol. 4, No. 6, pp. 438-452.

Hair, J.F., Black, W.C., Babin, B.J., Anderson, R.E. and Tatham, R.L. (2010), Multivariate Data Analysis, Upper Saddle River, Pearson, New Jersey.

Jacoby, J. and Chestnut, R.W. (1978). Brand Loyalty Measurement and Management. New York: Wiley.

Juhee Kang, Aikaterini Manthiou, Norzuwana Sumarjan \& Liang (Rebecca) Tang (2017) An Investigation of Brand Experience on Brand Attachment, Knowledge, and Trust in the Lodging Industry, Journal of Hospitality Marketing \& Management, 26:1, 1-22, DOI: $10.1080 / 19368623.2016 .1172534$ 
Jurnal Ekonomi, Bisnis, dan Akuntansi (JEBA) Volume 21 Nomor 03 Tahun 2019

Keh, H.T., Nguyen, T.T.M. and Ng, H.P. (2007), "The effects of entrepreneurial orientation and marketing information on the performance of SMEs", Journal of Business Venturing, Vol. 22, pp. 592-611

Kiyani, Talat M., Mohammad Raza Ullah K.N.,Riffat Abbas Rizvi, andImran Khan. 2012. "The relationship between brand trust, customer satisfaction and customer loyalty. (evidence from automobile sector of pakistan). Interdisciplinary Journal of Contemporary Research In Business. Vol. 4 (1). 489-502.

Kotler, Philip. 2005. Manajemen Pemasaran. Jilid I. Indeks, Jakarta.

Lam, S.K., Ahearne, M., Mullins, R., Hayati, B. and Schillewaert, N. (2013), “Exploring the dynamics of antecedents to consumer-brand identification with a new brand", Journal of the Academy of Marketing Science, Vol. 41, No. 2, pp. 234-252.

Lam, S.K., Ahearne, M.and Schillewaert, N. (2011), "A multinational examination of the symbolic-instrumental framework of consumer-brand identification", Journal of International Business Studies, Vol. 43, No. 3, pp. 306-331.

Lam, S.K., Ahearne, M.and Schillewaert, N. (2011), "A multinational examination of the symbolic-instrumental framework of consumer-brand identification", Journal of International Business Studies, Vol. 43, No. 3, pp. 306-331.

Mowen, John C. Mowen, Michael Minor. 2002. Perilaku Konsumen (Jilid 1), Edisi Kelima. Jakarta: Erlangga, 2002.

Odin, Y., Odin, N.and Valette-Florence, P. (2001), "Conceptual and operational aspects of brand loyalty: an empirical investigation", Journal of Business Research, Vol. 53, No. 2, pp. 7584.

Oliver, R.L. (1999), “Whence consumer loyalty?”, Journal of Marketing, Vol. 63, No. special issue, pp. 33-44.

Oliver, R.L. (1999), “Whence consumer loyalty?”, Journal of Marketing, Vol. 63, No. special issue, pp. 33-44.

Oliver, R.L. (2010), Satisfaction: A Behavioral Perspective on the Consumer(2nd edn.), ME Sharpe, Armonk, New York. 
Pengaruh Pengalaman Merek Terhadap Kesetiaan Merek Dimediasikan Oleh Kecintaan Merek, Kepercayaan Merek, dan Keterkaitan Merek

Olsen, S.O., Tudoran, A.A., Brunsø, K. and Verbeke, W.(2013), "Extending the prevalent consumer loyalty modelling: the role of habit strength", European Journal of Marketing, Vol. 47, No. 1/2, pp. 303-323.

Suliyanto. 2005. Analisis Data Dalam Aplikasi Pemasaran. Ghalia Indonesia, Bogor.

Widiyanto Agnes Fitria \& Rahab. (2017), "Community participation in bank of garbage: Explorative case study in Banyumas regency", Masyarakat, Kebudayaan dan Politik Vol. 30, Number 4, 2017, page 367-376. 